\title{
Foreign Private Investment and Poverty Situation in Nigeria 1981 To 2010: An Empirical Evidence
}

\author{
Panshak Yohanna \\ Department of Economics Plateau state University, Bokkos Pmb 2012 Jos-Plateau State Nigeria,
}

\begin{abstract}
The main aim of the research is to examine the impact of Foreign Private Investment (FPI) on poverty situation in Nigeria using secondary data from 1981 to 2010. The study employs Ordinary Least Squares (OLS) regression technique and other diagnostic tests such as unit root test for stationarity and cointegration. Findings from the study reveal that the variables are co integrated and stationary at first difference. The long run regression result shows that there exist a positive relationship between Foreign Private Investment and Per Capita Income in Nigeria. Thus, foreign capital reduces the prevalence of poverty in Nigeria. The study thus, recommends: creation of conducive domestic environment, transparent judicial system and redirecting inflow of foreign capital to poverty reducing sectors such as agricultural sector, education, health and power for meaningful and effective poverty reduction in Nigeria..
\end{abstract}

Key Words: foreign, private, investment, poverty.

\section{Introduction}

There has been a general consensus over the importance of capital in economic growth and development of any economy. But, economists, policy makers and analysts are sharply divided on the issue of whether economic resources should come from domestic or foreign sources. While pro-foreign investment believes that Foreign Private Investment (FPI) has the potentials of contributing to economic growth through: employment creation; transfer of technology and enhancing export competitiveness of the host economy with the attendant spillover effect on the quality of life. The questions of economic welfare and poverty are addressed better when domestic resources are augmented with foreign capital (Aremu, 2005). Contrary to the advocates of Foreign Private Investment(FPI), the Neo-Marxists believe that economic stagnation and poverty of most developing nations are explained based on the unequal trade and exchange relationships among nations from periods of slave trade through colonialism and today through FPI; direct and portfolio investment. (Aremu,2003; 2005)

Evidences from most countries have shown that domestic private investment is insufficient in giving the required boost to enable the achievement of development targets. This is because of the mismatch and gap existing between their capital requirements and saving capacity. Osinubi (2010) points out that FPI compliments domestic resources to enable the economy carry out effectively her development programmes and raise the standard of living of her people.

Foreign Private Investment simply represents those economic resources that originate from other economies invested in a domestic country. It is categorically made up of foreign direct investment and foreign portfolio investment. As Osunubi (2010) puts it, foreign direct investment is often referred as a means of boosting the economy. This is because foreign direct investment disseminates advanced technological and managerial practices through the host country and thereby exhibits greater positive externalities compared with foreign portfolio investment which may not involve positive transfers, just being a change in ownership having little impact on poverty of the host economy. Also foreign direct investment inflow is less influenced by fluctuations in national exchange rates as compared to foreign portfolio investment. Foreign direct inflows tend to be more stable than foreign portfolio investment because of the liquidity and short term horizon associated with the latter. It thus demands that a balanced mixture of the two would produce the expected benefits given the unique characteristics of the recipient economy (Lipsey, 1999).

\subsection{Benefits of Foreign Private Investment}

The benefits of Foreign Private Investment have enormous impact on the micro and macro economic prosperity of a nation. Some of the specific positive spillover effects of foreign capital include: First, macroeconomic theoretical exposition reveals that in a closed economy with no access to foreign savings, investment opportunities are financed only from the aggregate saving potentials of such economy. In an open economy like Nigeria however, access to foreign saving is capable of playing complementary role particularly where there is domestic shortfall of financial resources to meet investment demand (Okpe and Abu, 2009; Aremu, 2005). In this case poverty is particularly reduced when foreign capital does not "crowds-out domestic investment" 
Secondly, FPI most especially foreign direct nvestment encourages the transfer of technology. In a technology deficient economy such as Nigeria, foreign direct investment allows for the transfer of technology-particularly in the form of new varieties of capital inputs-that cannot be achieved through financial investments or trade in goods and services. Aremu (2005) points out that foreign investment especially Transnational Companies (TNCs) invest highly in research and development, entering into new alliances as well as re-organizing their production relations in readiness for "technological war". This development he maintained would impose stringent demands on host economies to prepare their environment ready or be relegated in the new global arrangement where the only language is technological innovation. Economic development and welfare are positively affected when the technology is directed to critical sectors of the economy like agriculture, health, education in the Nigerian case for meaningful poverty reduction.

Thirdly, foreign investment enhances export competitiveness. Studies show that most developing economies allow foreign capital inflow in order to upgrade their comparative advantage, particularly from exports of primary products to exportation of manufactured products. Most developing nations woo foreign investment inflow because of the believe that foreign capital acts as catalyst for restructuring of domestic enterprises directly involve in activities linked to their affiliates and indirectly by the subsequent emerging competition between domestic and foreign firms. Lateef (1997) reveals that such direct and indirect impact could be seen in computer software firms in India where subcontracting arrangements with TNCs upgraded Texas Instrument of India.

Fourth, promotion, generation and strengthening of the skill base of a country. Among important macroeconomic policy objectives of all economies irrespective of their level of development, with regard to employment are: reducing the unemployment level; move toward full employment position, and raising quality and welfare of the people. FPI in the host economy can generate and upgrade the host country's employment situation. This is achievable most when the investment is green field (i.e. new investment), labour intensiveness of the foreign capital, and import substitution investment. By exposing the domestic labour force into international labour market that is constantly experiencing increasing technological sophistication, foreign investment influences domestic labour force to become more technologically competitive than their domestic counterparts.

Fifth, it contributes to corporate tax revenue of the host economy. Increased revenue of a responsible government is directed to poverty reducing projects.

Other perceived benefits of FPI include: enhancement of balance of payment ability, higher per capita income, and diversification of industrial base and modernization. It suffices to assert that Foreign Private Investment has the potentials of reducing poverty and enhancing economic development ceteris paribus.

Since the 1980s, the flow of investment has increased in the world over. With the introduction of Structural Adjustment Programme (SAP) with its various liberalization and deregulation policies embarked in Nigeria, FPI in the forms of foreign direct and portfolio investment have grown significantly. It is however, pathetic that the economy is still bedeviled and characterized by low per capita income, high unemployment, poverty related social vices and slow pace of economic growth and development. These challenges are theoretically expected to be addressed by the inflow of Foreign Private Investment.

Today, Nigeria is ranked among the poorest nations of the world. In 2011, poverty rate in Nigeria stood at 71.5 per cent with unemployment rate, GDP per capita and human Development index at 23.9. N226, 920.19 and 0.43 respectively, (NPC, 2011). This perhaps suggests the higher concentration of FPI in lucrative sectors (Oil and Gas; Telecommunication, Portfolio investment etc) with insignificant regards to sectors such as agriculture, health, education etc which have higher propensities to remove Nigeria from the lingering poverty situation.

As a result of the above, it becomes relevant for a study like this to investigate if there exists any relationship between FPI and poverty reduction in the Nigerian economy. The rest of the study is structured into four sections. Section two reviews theoretical and empirical studies related to the research. The methodology is covered in section three. Section four is data analysis and discussion of major findings. Lastly, section five concludes and submits policy recommendations.

\section{Review Of Theoretical Literature}

Conceptual, ideological and theoretical issues in Foreign Private Investment have ignited series of contentious debates on the impact and direction of foreign capital across nations. Two distinct schools of thought emerged to answer questions surrounding foreign investment.

On one hand stands the modernization school of thought dominant in comparative political development studies in 1950s and 1960s ( Rostow,1960; McClelland,1964; Apter,1965), in conjunction with the present neo-classical development economics ( Sachs and Lipton, 1990; 1991; Blanchard 1993; Aslund, 1995). On the other end are the dependency theorists who believe that foreign investment especially on the shores of the developing economies explains the discrepancies in economic development the world over. Foreign 
investment; direct or portfolio serves only to enrich the West and further impoverish the poor nations of the world (Aremu, 2005).

From classical through Neo- Classical and the Neo-liberal schools of thought (pro-foreign investment) believe that foreign investment could provide the much needed mechanism for economic growth and poverty reduction in capital deficient economies if and only world economic system is determined by price mechanism ( forces of demand and supply).

In contrast to the position and submission of the liberalists, the Marxist, Neo- Marxist or the dependency framework view FPI as the advance guard for a new diplomacy of economic imperialism producing stagnation, underdevelopment and poverty in unsuspecting developing nations of Africa, Asia and Latin America (Okpe and Abu, 2009; Aremu, 2003, 2005).

Despite the submissions of the dependency school of thought, Ray and Webster (1978) argue that many Latin American countries that depended substantially on foreign capital have grown faster than their African counterparts. This trend is also noticeable among South- East Asian developing economies.

Other arguments explaining the desirability or otherwise of Foreign Private Investment have emerged over the years. For instance, the Factor Price Equalization Theorem of Hechscher-Ohlin model believes that foreign investment would continue to move in response to changes in rates of returns on them until the returns equalizes across national boundaries. This simply means that capital is expected to move from capital abundant economies like the West to capital scarce economies like Nigeria in response to higher marginal productivity until the rates of returns are identical in both host and parent country.

Theory of the firm explanation follows Caves (1974) that a firm will continue to invest at home until optimum level of investment at home is reached and further investment will make marginal cost to be higher than average cost and price per output. This theory functions well using microeconomic behavior of firms.

Aremu (1997) submitted that FPI accelerates the pace of economic development of developing countries up to a point where a satisfactory rate of growth can be achieved on a self-sustaining basis. This implies that foreign capital has the capacity of enhancing sustainable development and poverty reduction. Similarly, Okpe and Abu (2009) argued that the main aim and responsibility of FPI in developing economies like Nigeria is to raise the standard of living of its people. They concluded that Foreign Private Investment should continue to grow until a certain level of income is reached and poverty situation is drastically reduced. The benefits of foreign investment differ from country to country depending on the country characteristics and the level of economic development.

\subsection{REVIEW OF RELATED EMPIRICAL STUDIES}

The impact of FPI on particularly developing economies like Nigeria has remained an area of intensive debates over decades. It has been acknowledged in developed economies that FPI exerts significant positive impact on economic growth. Osunubi (2010) observes that the impact varies from country to country and it is a function of country characteristics, policy environment and sectors. In consonance with the above, Blomstrong and kokko (1997) evaluate empirically the impact of foreign direct investment a component of FPI on host economy and concluded that Multinational Companies (MNCs) may play crucial role for productivity and export of their host countries, but that the exact nature of impact FDI varies between and countries, depending on country features.

Ewe -Ghee Lim (2001) summarizes recent findings on foreign direct investment and its correlation with economic growth focusing on literature regarding spillovers foreign direct investment and finds that while substantial support exists for positive spillovers from foreign direct investment, there is no consensus on causality.

Empirical evidences from developing countries show that they do not benefit substantially from Foreign Private Investment and often face the challenge of crowding out of domestic private investment hence the prevalence of poverty and economic backwardness. (Kumar and Pradhan, 2002)

Mishara and mody (2001) established that Foreign Private Investment has been associated with higher growth in some advanced countries. Within the Less Developing Countries (LDCs), however, Foreign Private Investment is associated with high incidence of crises. This is to a larger extent true with the experiences of Nigeria with the hostility in Niger-Delta region before the amnesty of the federal government in 2007/2008.

Using Nigerian data, Okpe and Abu (2009) investigate the impact of FPI on poverty reduction and discovered that Foreign Private Investment and foreign loan significantly alleviate poverty in Nigeria. Similarly, Ayashagba and Abachi (2002) carry out empirical analysis on the effect of Foreign Private Investment on economic growth and the result showed that Foreign Private Investment had significant impact on economic growth. They concluded that the presence of Foreign Direct Investment (FDI) in the Nigerian economy is not completely useful. Using Error Correction Mechanism (framework), Akinlo (2004) investigates the impact of foreign direct investment on economic growth of Nigeria from 1970-2001 and concluded that both private capital and lagged foreign capital have significant effect on economic growth. 
Ayanwale and Bamire (2004) present a positive and significant effect of foreign direct investment on firm's productivity of both domestic and foreign firms in the Nigerian Agro/agro allied sector. Conceptually and empirically analyzing the desirability or otherwise of foreign capital, Obadan (2004) asserted that the impact of foreign private capital depends on the use to which such capital is put. According to him, foreign capital if channeled into productive uses, can be highly desirable, as it will bring about the much needed economic growth and development.

Osinubi and Amaghionyediwe (2010) recently establish empirically that FPI has positive impact on economic growth rate in Nigeria. They concluded that issues surrounding Foreign Private Investment should not be ignored in policy decisions aimed at promoting the economic welfare and prosperity of all and sundry.

\subsection{Concept of Poverty and Poverty Alleviations Efforts In Nigeria}

In 1997 the Human Development Report of the United Nations Development Program (UNDP) defines poverty as deprivation and denial of choices and opportunities most basic to human development, as well as lack of the ability to make choices and use available opportunities purposefully. Poverty has been viewed as multidimensional and hydra headed evil affecting the quality of life of people. It knows no limit as it poses a challenge on any category of the population. According to Englama and Bamidele (1997) it is a situation where an individual cannot meet his / her basic needs of food, shelter, clothing, has low calorie intake and cannot acquire the requisite skills, low education, low assets, no portable water, low health and life expectancy, low income, is unemployed and or under employed. It is the inability to achieve a certain minimal standard of living. Bradshaw (2006) observes that it is simply the lack of necessities while Obadan (1997) summarizes poverty as lack of physical accessories, assets and income.

Poverty can be classified into absolute, relative and subjective poverty (Okunmadewa, et al 2010). The absolute measure of poverty is defined based on a minimum level of income, usually 1 dollar. Where an individual lives on less than a dollar per day (PPP) such an individual is classified as been poor. Relative poverty has to do with comparing between individuals in the same stare of income stream, where a household or individual can be said to be less poor or chronically poor. It is the failure of individuals to meet up with the mean income in a given group where they are categorized. This extends to the entire society when an individual's income falls short of the society's mean income, he is relatively poor. The perception of an individual concerning his material well being and economic standing in relation to others determines whether he is subjectively poor or not. Where the individual perceives himself as been poor based on his own chosen yardstick then, he is poor (Abimiku, 2006; Todaro and Smith, 2009). Poverty according to the discoveries of Ajakaiye and Adeyeye (2001) could be classified as structural (chronic) and transient. The former is persistent or permanent socio-economic deprivations caused by a host of factors such as limited productive resources, inadequate skills for gainful employment, endemic socio cultural and political factors etc while the latter is temporary in nature and is as a result of natural and manmade disasters.

Although poverty is a world-wide issue, Nigeria is a country that seems to be caught in its detrimental cycle. Many Nigerians are faced with the consequences of poverty: hunger, malnutrition, illiteracy, disease, life of misery and squalor, low life expectancy, socio-political insatiability, bribery and corruption, crime, violence, prostitution, alcoholism, drugs addiction, frustration despair, disillusionment, pessimism and moral decadence. Poverty is increasingly being recognized as both a policy and economic problem in Nigeria. This is stressed by the Nigerian Poverty Reduction Paper called needs document as well the poverty and vulnerability assessment of the country (Okunmadewa, etal, 2010). In Nigeria, poverty alleviation programme is as old as national development plan. The objective of poverty alleviation programmes according to Okpe and Abu (2009) depends on government macroeconomic agenda. A lot of poverty alleviation programmes were implemented before and after the Structural Adjustment Programme (SAP) such as: River Basin Development Authorities (RBDA), Agricultural Credit Guarantee Scheme (ACGS), Operation Fed the Nation (OFN) 1977, Green Revolution (GR) 1988, Directorate of Food Roads and Rural Infrastructure (DFFRI), National Directorate of Employment (NDE) in 1986, Small Scale and Medium Enterprises, Petroleum Trust Fund (PTF), National Poverty Eradication Programme (NAPEP) etc.

Because of the perceived shortfall in domestic economic resource to significantly reduced the prevalence of poverty most especially in developing countries like Nigeria, successive governments have implemented several strategies for attracting foreign investment in order to alleviate widespread poverty and advance welfare of the masses. Foreign direct investment, portfolio investment and other related capital are expected to raise the standard of living of the population. Whether foreign capital has succeeded in mitigating poverty situation or not is subject to analytical or empirical investigation. For the transformation agenda of the government to achieve its objective, FPI must be significantly directed to sectors that have the capacity to meaningfully reduce poverty in the economy. 


\section{Methodology}

This research covers the period 1981 to 2010. The choice behind the period is based on the fact that the scope coincides with the liberalization, deregulation and privatization exercises undertaken as well as concerted efforts geared toward reducing poverty through various means with greater focus on attracting foreign capital in. The period also coincides with the campaign of the 'transformation Agenda' of the Nigeria democratic government to attract Foreign Private Investment for investment in various critical sectors of the economy. This would essentially help in the quest to be among the top 20 most industrialized nations in the world by the year 2020. Secondary data for the period 1981 to 2010 used for the analysis were sourced from Central Bank of Nigeria statistical Bulletin, National Planning commission, National Bureau of Statistics, CBN annual reports, journals, bullions and text books.

\subsection{Variables Under Study}

The major variables under investigation are Foreign Private Investment and Per capita income. Foreign Private Investment is the summation of all inflow of foreign capital across all sectors. To capture or measure poverty level, per capita GNI is used since it is a welfare indicator. In order to measure specific impacts, domestic private investment, nominal exchange rate, foreign loan and export are included in the model analysis

\subsection{MODEL SPECIFICATION}

The methodology employed follows Osinubi and Amaghionyediwe (2010) derived from a neoclassical aggregate production. The function is stated as below:

$P C I=F(F P I)$

To determine whether FPI promotes export and does not crowd out domestic investment we include value of exports and gross fixed capital formation to measure respectively export and domestic investment. Foreign capital may be restructured inform of external debt hence its inclusion. The exchange rate is included to determine the cost and flow of capital across borders. Thus, the function is;

$P C I=F(F P I, F L N$ EXR DIV, XP)

The long run model to be estimated is as follows:

$P C I=\alpha+\beta 1 F P I+\beta 2 F L N+\beta 3 D I V-\beta 4 E X R+\beta 5 X P+\mu$

Where:

$P C I=$ Per capita income

$F P I=$ Foreign Private Investment

$F L N=$ Foreign loan

$D I V=$ Domestic private investment

$E X R=$ Exchange rate

$X P=$ Export

$\mu=$ innovation or the error term

$\alpha, \beta=$ the autonomous component and parameter estimates of the variables respectively.

The a prori expectation of the research follows economic literature. Therefore, Foreign Private Investment, foreign loan, domestic investment, and export are expected to exert positive impact on per capita income, proxy of poverty. It is expected that exchange have inverse relationship with per capita income.

\subsection{ESTIMATION PROCEDURES}

The econometric technique employed is Ordinary Least Squares (OLS). Stationarity tests are carried out on the model variables using Augmented Dickey-Fuller (ADF) unit root test method. Co-integration test is conducted on the residuals of the variables to determine the presence or otherwise of any long run equilibrium in the model. Other diagnostic tests such as R - squared, statistical test of significance (T-test and F-test), and Durbin Watson statistics are used to interpret the results. The application software used is E-view 7.1.

\subsection{UNIT ROOT TEST RESULTS}

\section{Data Analysis And Evaluation Of Empirical Results}

Using Augmented Dickey-Fuller test all variables are non-stationary at level. However, at their first differences, all variables are stationary except domestic investment, per capita income and export.

\section{The hypothesis}

- The null hypothesis $\left(\mathrm{H}_{0}\right)$ : $\mathrm{U}=0$ there is the presence of unit root in the variables hence Non stationary

- The Alternative hypothesis $\left(\mathrm{H}_{1}\right): \mathrm{U} \neq 0$ there is no unit root in the variables hence, Stationary 
Results of the Augmented Dickey-Fuller (ADF) test the variables revealed that the variables exhibit random walk. Since, there exist some non-stationary series in the model, we need to conduct co integration test to determine the presence or otherwise of any long-run relationship.

\subsection{CO-INTEGRATION TEST RESULT}

Running analysis with non-stationarity variables would produce spurious results. In order to resolve this problem we conduct co-integration test on the residuals of the static regression analysis using Eagle and Granger methodology. Eagle and Granger make use of ADF unit root on the residuals obtained from the OLS regression model. It shows that the variables are co integrated at 5\% level of significance, since the mackinnon $\mathrm{p}$-value is less than the level of significance $(0.0191<0.05$. See appendix 1$)$.

\begin{tabular}{|c|c|c|c|}
\hline \multicolumn{4}{|c|}{$\begin{array}{l}\text { APPENDIX } 1 \text { CO INTEGRATION TEST : ADF UNIT RO } \\
\text { Null Hypothesis: UT has a unit root } \\
\text { Exogenous: Constant } \\
\text { Lag Length: } 0 \text { (Automatic - based on SIC, maxlag=6) }\end{array}$} \\
\hline & & t-Statistic & Prob.* \\
\hline \multicolumn{2}{|c|}{ Augmented Dickey-Fuller test statistic } & -3.400378 & 0.0196 \\
\hline \multirow[t]{3}{*}{ Test critical values: } & $1 \%$ level & -3.689194 & \\
\hline & $5 \%$ level & -2.971853 & \\
\hline & $10 \%$ level & -2.625121 & \\
\hline
\end{tabular}

\section{APPENDIX 2 LONG RUN REGRESSION ANALYSIS}

\begin{tabular}{|c|c|c|c|c|}
\hline \multicolumn{5}{|c|}{$\begin{array}{l}\text { Dependent Variable: PCI } \\
\text { Method: Least Squares } \\
\text { Date: 02/12/13 Time: 08:13 } \\
\text { Sample: } 19812010 \\
\text { Included observations: } 30\end{array}$} \\
\hline Variable & Coefficient & Std. Error & t-Statistic & Prob. \\
\hline FPI & 0.080884 & 0.410966 & 0.196814 & 0.8456 \\
\hline FLN & 0.077183 & 0.040276 & 1.916338 & 0.0673 \\
\hline XP & -0.021648 & 0.024504 & -0.883432 & 0.3858 \\
\hline EXR & -1758.086 & 1845.063 & -0.952860 & 0.3502 \\
\hline DIV & 0.246056 & 0.106142 & 2.318181 & 0.0293 \\
\hline $\mathrm{C}$ & -12067.98 & 26348.40 & -0.458016 & 0.6511 \\
\hline R-squared & 0.528772 & \multicolumn{2}{|c|}{ Mean dependent var } & 65300.70 \\
\hline Adjusted R-squared & 0.430599 & \multicolumn{2}{|c|}{ S.D. dependent var } & 125805.2 \\
\hline S.E. of regression & 94930.89 & \multicolumn{2}{|c|}{ Akaike info criterion } & 25.93654 \\
\hline Sum squared resid & $2.16 \mathrm{E}+11$ & \multicolumn{2}{|c|}{ Schwarz criterion } & 26.21678 \\
\hline Log likelihood & -383.0481 & \multicolumn{2}{|c|}{ Hannan-Quinn criter. } & 26.02619 \\
\hline F-statistic & 5.386147 & \multicolumn{2}{|c|}{ Durbin-Watson stat } & 2.912530 \\
\hline Prob(F-statistic) & 0.001849 & & & \\
\hline
\end{tabular}

The result of the long-run regression analysis is given as:

$\mathrm{PCI}=-12067.98+0.025 \mathrm{DIV}+0.08 \mathrm{FPI}+0.077 \mathrm{FLN}-0.020 \mathrm{XP}-1659.9 \mathrm{EXR}$

$\mathrm{R}^{2}=0.53 \mathrm{DW}=2.91 \mathrm{~F}-\mathrm{stat}=5.39$

The long run regression results are largely in conformity with a prori expectation. The regressors: Foreign Private Investment (FPI), Domestic Investment (DIV), and Foreign Loan (FLN) exert positive impact on Per Capita Income (PCI) and by implication poverty is reduced. Export (XP) and Exchange Rate (EXR) negate research expectations. 
The coefficient of FPI is 0.08 . Hence, a unit increase in foreign investment in the economy, per capita is increased by 0.08 . This indicates that the welfare of the citizens is enhanced ceteris paribus. It should be however noted that the effect is not statistically significant at $5 \%$.

The basic objective of contracting foreign loan most especially in developing countries like Nigeria has been to augment domestic resources for effective production and poverty reduction. Based on the result, foreign loan exerts positive effect on per capita income. If external debt is judiciously used poverty would be mitigated. Its insignificant influence may be attributed to the fiscal indiscipline and corrupt tendencies of government officials over the years.

The coefficient of domestic investment is positive and statistically significant. This is an important policy variable to reducing poverty situation in Nigeria. Thus, more efforts at increasing gross fixed capital formation would be expedient in addressing the scourge-poverty in the economy.

Export is negative for the period selected for the analysis. This may be as a result of: production and exportation of primary products, inadequate exports and import dependent nature of our economy. The exchange earnings on Nigerian export is insignificant in addressing the prevalence of poverty in the country. This perhaps could also be explained by the way foreign exchange earnings are diverted to private treasuries at the detriment of the masses

Exchange rate is correctly signed. Thus, as exchange rate rises per capita income reduces. This implies an in increase in poverty and vice versa.

Based on the R-Squared result of $0.53,53 \%$ of total variation in poverty is explained by the independent variables in the model. Thus, the regressors significantly affect per capita income in Nigeria for the sample period.

Co integration test conducted addressed the dangers of encountering spurious results. Therefore, there exists a long run linear combination between the variables. Because of the stationarity of our variables and because the $\mathrm{R}^{2}$ is less Durbin-Watson statistics, we concluded that there is no serial correlation in the model given Durbin-Watson Statistics of 2.91. F-statistics result shows that the regressors jointly explain variation in poverty situation in Nigeria since F-statistics is less than the level of significance; $0.0018<0.05$.

\section{Conclusion and Recommendations}

The main aim of this research is to examine the impact of Foreign Private Investment on poverty situation in Nigeria using secondary data from 1981 to 2010. The study reveals that Foreign Private Investment in Nigeria has positive impact on per capita income an index of socio-economic welfare. Also, it was discovered that the impact of most variables on poverty reduction is not statistically significant at the chosen level of significance. This may be adduced to the direction and concentration of foreign investment in Nigeria to perceived lucrative sectors against critical and poverty reducing sectors such as agricultural, educational and power sectors. Most foreign capital is concentrated in the oil, telecommunication and equity. If poverty would be significantly reduced, agriculture most be given adequate attention given that it employs more than $60 \%$ of the entire population. The findings of this research are in conformity with the empirical works of: Osinubi, 2010; Okpe and Abu, 2009; Aremu, 2005. The study establishes that export and exchange rate were not in line with the research expectation. This is probably because of the balance of payment disequilibrium that has characterized the economy over time.

Based on empirical findings of the study, some policy recommendations are provided as given below; Foreign Private Investment should be given much priority and pursued as national goal. Redirecting foreign capital to poverty sensitive sectors like agriculture and education would go a long way to reducing poverty prevalence in Nigeria. Fiscal discipline, creation of viable infrastructure and efficient judicial system would play pertinent role to attracting foreign capital in Nigeria. Efforts should be geared by the government to reduce exchange rate distortions and or misalignment, increase export of locally manufactured goods in a quest to raise the value of the local currency, the naira; earn more foreign exchange. This policy effort will most likely result in increased capital formation in Nigeria needed for overall economic transformation and poverty reduction. Foreign loan and domestic investment should be managed efficiently to enhance economic prosperity and improved quality of life of the masses.

\section{References}

[1]. Abimiku, A.C. (2006). A Review of Concepts and Measurements of poverty. Journal of Contemporary Issues on Poverty, 1(1).

[2]. Agarwal,J.P (1980). Determinants of Foreign Direct Investment: A Survey, a Weltwirtschafsliches Archive, 116:739-732

[3]. Aigbokhan, E. (2000). Poverty, Growth and Inequality in Nigeria: A Case Study. African Economic Research. Nairobi.

[4]. Akinlo, A.E. (2003). Globalisation, International Investment and stock Market in Sub-saharan Africa. Institute of Developing Economics, Jethro, Japan.

[5]. Ajakaiye, O. and S.A. Adeyeye. (2001). Concept, Measurements and Determinants of Poverty. Central Bank of Nigeria. Economic and Financial Review, 39(4).

[6]. Ake, C. (1996). Democracy and Development in Africa. Ibadan: Spectrum Bookshop ltd.

[7]. Anyanwu, J.C. (1998) An Econometric Determinants of FDI in Nigeria. Nigeria Economic Society, Annual Conference publication 
[8]. Anyanwu, J. C. (1998). An Econometric Investigation of the Determinants of Foreign Direct Investment in Nigeria: Rekindling Investment for Economic Development in Nigeria. Selected Papers in Annual conference, Nigerian Economic Society, Ibadan.

[9]. Aremu, J. A. (1997). Foreign Private Investment: Determinants, Performance and Promotion. CBN Bulletin, 108-112.

[10]. Apter, D. (1965). The Politics of Modernization, Chicago press.

[11]. Aslund, A. (1995). How Russia Became a Market Economy. Washington: Brooking institution

[12]. Ayanwale, A.B. (2007). FDI and Economic Growth: Evidence from Nigeria. AERC Research Paper 165, African Economic Research Consortium, Nairobi

[13]. Ayashagba, G.I.,and Abachi, P.I. (2002). The Impact of Foreign Direct Investment on Economic Growth of LDCs: A Case of Nigeria (1980 -1997). Journal of Economics and Social Research, 1:108-125.

[14]. Blanchard, O. (1993) Post communist Reform: Pain and Progress. Cambridge , M.A London(England): The MIT press.

[15]. Blomstrom, M., Denise K. and Robert, E. L. (2000). Determinants of Foreign Direct Investment in The Restructuring of the Japanese Economy. NBER Working paper 693.

[16]. Bradshaw, T.K. (2006). Theories of Poverty: The Culture of poverty. Available at www.blacksacademy.co.uk

[17]. Caves, R. E. (1974). International Corporations: The industrial Economics of Foreign investment. Economica, 3:1-27. http://dx.doi.org/10.2307/2551748.

[18]. Central Bank of Nigeria. (1999). Nigeria's Development Prospects. Poverty Assessment and Alleviation Study.

[19]. Dornbusch, R., \& Reynoso, A. (1989). Financial Factors in Economic Development. American Economic Review, 79(2), 204-209. Available at http://dx.doi.org/10.2307/2534470.

[20]. Dunning, J. H. (1993b). Introduction: The Nature of Transnational Corporations and their Activities. In J. H. Dunning (Ed.), The Theory of Transnational Corporations London and New York: Routledge. 1:1-16.

[21]. Ekpo, A. H. (1995). Foreign direct investment in Nigeria: Evidence from time series data. CBN Economic and Financial Review, 35(1), 59-78.

[22]. Englama, A., and A. Bamidele. (1997). Measuremant Issues in Poverty Alleviation in Nigeria. Proceedings of NES Annual Conference.

[23]. Lipsey, R. E. (2001). Foreign direct investors in three financial crises. NBER Working Paper No. 8084, Cambridge, MA. Available at http://www.nber.org/papers/w8084.pdf

[24]. Jhingan, M.L. (2001). International Economics. Vrinda publications Ltd, Delhi. 5th edition.

[25]. Markusen, J. R. (1997). Trade versus investment liberalisation. NBER Working Paper No.6231. National Bureau of Economic Research, Cambridge, MA.

[26]. Masayuki, H and F. Ivohasina (2005). The Determinants of Foreign Direct Investment into Japan. Kobe University Economic Review, 51.

[27]. McClleland, D. (1964). Business Drive and National Achievement in amatai, E and Etzioni(eds) Social Change, New York: Basic Books

[28]. Mishara, D.A., and Mody, A.P. (2001). Private Capital Flows and Growth Finance. Development. 2, 2-3.

[29]. Moore, M.O. (1993). Determinants of Manufacturing Direct Investment 1980-1988. Weltwirtscaftsliches Archive, 129:120-137.

[30]. National Planning Commission. (2012). Performance Report on the Nigerian Economy.

[31]. Nwaobi, G.C. n.d. Solving the Poverty Crisis in Nigeria: An Applied General Equilibrium Approach. www.myprofile.cos.com/genwaobi.

[32]. Obadan, M. (1997). Analytical Framework for Poverty Reduction: Issues of Economic Growth Versus Other Strategies. In: Poverty Alleviation in Nigeria. Proceedings of NES Annual Economic Conference.

[33]. Obadan, M.I. (2004), Foreign Capital Flows and external debt: Perspective of on Nigeria and LCDs Group, Broadway press limited.

[34]. Obwona, M. B. (2001). Determinants of FDI and Their Impacts on Economic Growth in Uganda. African Development Review, 13(1), Pp 46-80. Available at $\quad$ http://dx.doi.org/10.1111/1467-8268.00030

[35]. Oke, B.O; Ezike, J.E; and Ojogbo, S.O (2012). Locational Determinants of Foreign Direct Investment in Nigeria in Nigeria. International Business Research, Available at http//dx.doi.org/10.5539/ibr.v5n4pp103.

[36]. Okunmadewa, F.Y.(1999). Overview of the Measurement of poverty and inequality. Centre for Econometric and Allied Research, University of Ibadan, Ibadan Nigeria.

[37]. Onwioduokit, A.E.(2006). Character of Unemployment in Nigeria and its links with the Macro economy. In: Employment Generation in Nigeria. Selected Papers for the 2006 Annual Conference.No.1.

[38]. Osinubi, T.S. and Amaghionyeodiwe, L.A. (2010), Foreign Private Investment and Economic Growth in Nigeria. Review of Economic Business Studies, Vol. 3 Issue 1, 105-127. ISSN-1843-763X

[39]. Prakash, L., and Assaf, R. (2001). How Beneficial is Foreign Direct Investment for Developing Countries. Finance and Development, 38(2):7-9. Available at http://www.imf.org/external/pubs/ft/fandd/2001/06/loungani.htm

[40]. Ragazzi, G. (1973), Theories of The Determinants of Foreign Direct Investment, The IMF staff papers, 20: 471-498.

[41]. Root, F. R. (1990). International Trade and Investment (5th ed.) (pp. 425-469). South Western Publishing Co.

[42]. Rostow, W.W. (1960). The Stages of Economic Growth. London: Cambridge University Press.

[43]. Sachs, J., and Lipton, D. (1990). Poland Economic Reform Foreign Affairs, Summer:47

[44]. Todaro, M.P., and Smith S.C. (2009). Economic Development. Tenth Edition. Pearson education limited. Essex, England.

[45]. World Bank. (2010). World Development Indicators. Washington, D.C.

[46]. The World Bank. World Bank. (2011). Migration and Remittances Factbook 2011. The International Bank for Reconstruction and Development / The World Bank, 2nd Edition. 